シン軟高によって病勢の刺激あるいは堌覀は認められな かった。

\section{IV. 総括および結語}

I. Trichomonas foetus の感染により, 不妊, 不

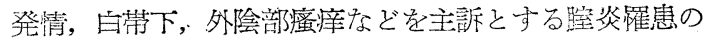
牡牛 4 例 (就中 1 例は子㗬内膜炎倧発) にトリコマイシ ンを治政実駼に用いて次記の成績を得た：一

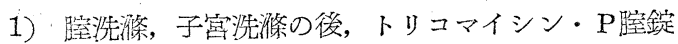

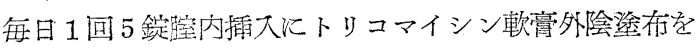
併用し, $1 \sim 3$ 日, 平均 2 日で原虫の消失を認め, 臨床 症状も同時に僌快した。

2) 臨床症状の軽快とともに, 胵滲出液は $\mathrm{pH} 8.0$ 8.6 から pH 6.0 6.4 ‡で下がり，子㗬滲出液は $\mathrm{pH}$ 7.4 から pH 6.2 まで下がって正賞の状態複し, ま た，混在細菌执よび白血球の消失を見た。

3）培㦈試験で原虫陰性を確めてからも, 治潦を中止 せず，結局，6〜10日まで継総し. それによって全例に 再登を見なかった。

II. Trichophyton (asteroides?) 《上万百瘦菌症の 乳牛 2 例にトリコマイシンの臨床芯用を試みて次記の成 績を得た：一

1）加里石簽を以って痂皮を軟化除去し，滅菌生理食 塭水で浸軟洗拭した後，トリコマイシン軟膏を毎日 1 2 回塗有し，第1例に和いては16日で全治に近い著效を 認めた。

2）第 2 例は，黄色苜萄状球菌との混合感染と診定さ れたので,トリコマイシン軟膏 $1 \mathrm{~g}$ にペニシリンGナト リウム璀結晶 5 万単位を混和して用いて 9 日で全治の結 果を得た・トリコマイシンは，眰錠として腔内に用いて
も，軟膏として皮慮に多量に塗布しても，何らの副作用 は認められない。従来, 難治を謳われた畜牛のトリコモ ナス症と白癄菌症に対して，このように有效適切な接生 物筫の登場を見たことは，わが獣医学界にとっても近来 の快事といわねね゙ならない・トリコマイシン結晶をバイ アルに充填し，随時水溶液とする便宜方与壳られれば，

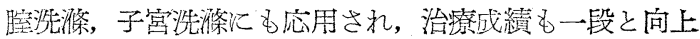
するであろらと信ずる。

㨽筆に臨み，御愁篤な御指尊々御校閶を賜わった恩師 登倉教授並びに御教示を頂いた后染病砢究所細谷教授に 謹謝し,トリコマイシンを提供された藤沢㰒品工業株式 会社に感謝の意を坛します。

$$
\text { 文献 }
$$

1) 二村, 折原: 家染衛生協会報, 3(1) : 1 36, 1935. 2) HOSOYA, S., KOMATSU, N., SOEDA, M. \& SONODA, Y.: Japan. J. Exp. Med., 22(6):505 509, 1952. 3) HOSOYA, S., KOMATSU, N., SOEDA, M., YAMAGUCHI. T. \& SONODA, Y. : J. Antibiotics, 5(10) : 56.1 566, 1952. 4) HOSOYA, S., SOEDA, M., KOMATSU, N., OKADA, K., TANABE, S. \& ONODA, Y.: $J$. Antiobiotics, $S \cdot A, 6(2)$ : 92 97, 1953. 5) 細谷: 日本化学潦法学会䧴 諗, $2(1): 1 \sim 14,1954.6)$ 細谷: 最新医学, $9(3): 291 \sim 296,1954$. 7) INOKI, S. \& HAMADA, Y. : J. Infect., Dis., 92(1):1 3, 1953. 8) 入江：獣医界, No.22, 13 19, 1949. 9) 真柄, 䌋野：座 婦人科の世界，6(1)：28３0，1954.10）水野：産嬠人科の世界，6(1)： $31 \sim 35$, 1954. 11) MORGAN, B.B.: Bovine Trichomoniasis, Mineapolis，1944. 12）高橋, 相沢：真菌（糸状菌）・䓆生物贒検查 法, 東京, 1951. 13) TRUSSELL, R.E. : Trichomonas vaginalis and T'richomoniasis, Oxford, 1947. 1.4) 藤沢莯工編誉 :トリコマイ

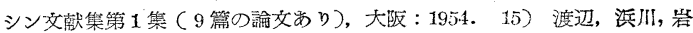

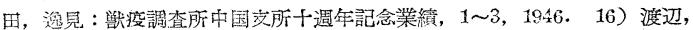
浜川, 岩田, 福見：ペニシリン，1(10):677〜682，1948，17）WATANABE M., YAMAUCHI, M., TSUNEKANE, T., TANABE, K., MORISHIMA,S.\& MORITAKI, M. : $J$. Antibiotics, $4(4): 224 \sim$

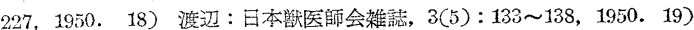

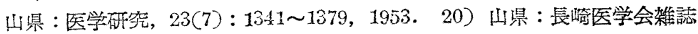
28 (9) : 991 994, 1953.

\title{
パラチオン中毒にっルて
}

\section{II・ノアトロピンによる治療試験}

梶山松 生*

パラチオン中毒の聖薬としてすでにアトロピンが用い られているが，これはアトロピンの特異作用である自律 神経の分在されている末梅の臓器に最初から麻瘦を発す る作用、すなわちパラチオン中毒の場合, Acetyl-choline

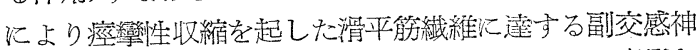
経系に属寸運動神経の未梢の麻瘦のために，その痤攣な ぞの発作学静止せしめるためと考允られる・しかし一方 に和いては，中枢神経を侵すために心搏増加などの諸種 の弊害があるために, 上田ら5) は人のパラチオン中毒に 関して予防的に作業後, アトロピンを用いるのは非常に 行き過ぎで, 却ってアトロピンの作用で苫しも人がある そいう.ここに拈いて，アトロピンによる Ch. E. の変 * 山口市 開業
動，注射時期特よび量などに関しての知㫕を補遺すべく 少数ではむるが，笑駼を試みたので結果染報告する。

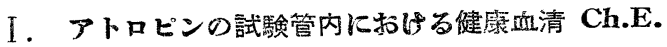
にちる澡す影響 Atropinum sulfuricum を階段稀积

第 1 表 試験管内作用

\begin{tabular}{|c|c|}
\hline Buffer solution + & Ch. E. Activity. \% \\
\hline Normal serum + Atropin $0.05 \%$ & 100 \\
Normal serum + Atropin 0.005\% & 100 \\
Normal serum + Atropin $0.0005 \%$ & 100 \\
Normal serum + Atropin $0.00005 \%$ & 100 \\
Atropin $0.05 \%$ & 0 \\
Atropin $0.005 \%$ & 0 \\
Atropin $0.0005 \%$ & 0 \\
Normal serum & 100 \\
\hline
\end{tabular}


乙て健康血清を同量宛加えて既述のごとく柴田, 高橋沠 飞したがって Ch. E. の活性価を調查した結果, 第 1 表 の示すごとくアトロピン自体は何ら Ch. E. に対して影 響を和よぼさない。

II. アトロピンの生体内反応 当 $\mathrm{kg}, 0.1 \mathrm{mg}$ の Atropinum sulfuricumの皮下注射によって血糖は30分後 より60分後まで $10 \mathrm{mg} / \%$ 減少を示し, 血色素量法い ても多少の増減は認められたが, 顕著な変化はなく, 血 清 Ch. E. についても, これを增加せしめる作用は全然 認められなかった. 同量を静脈内注射した場合, 10分後 には血糖の $21 \mathrm{mg} / \%$ 増加を認めたことは軽度の肝臟障 害のあることを疑わしめる。血色素量は大差なかった が，むしろ少数ながら減少している.血清中の Ch. E. 飞変動はなかった。以上湾より当 $\mathrm{kg} .0 .1 \mathrm{mg}$ 程度の皮 下注射ならば生体に大きな影響は無いものと思われる。 (第 2 表)

\section{III．パラチオン中毒時のアトロピン適用に関する試験}

第 5 例, 第 7 例は最底致死量当 $\mathrm{kg} .4 \mathrm{mg}$ パラチオン を与えられたるので，第 5 例は提取後 1 時間 18 分後, 発 症後48分の時 Atropinum sulfuricum 当 $\mathrm{kg} 0.1 \mathrm{mg}$ を皮下注射した。第 7 例はパラチオン投与前 20 分に皮下 注射, 瞳孔散天するに敃よびホりドール原液をパン片

\begin{tabular}{|c|c|c|c|c|c|c|c|}
\hline & & 静 & 眽 内 注 & 㑗措 & 皮 & 下 注 & 射 \\
\hline 時 & 間 & $\begin{array}{c}\text { Ch. E. } \\
(\%)\end{array}$ & $\left.\mid \begin{array}{ll}\text { Iff } & \text { 糖 } \\
(\mathrm{mgg} / \%)\end{array}\right]$ & $\begin{array}{l}\text { 衁色菜 } \\
(\%)\end{array}$ & $\begin{array}{c}\text { Ch. } E . \\
(\%)\end{array}$ & 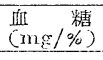 & $\begin{array}{l}\text { 血侮琴 } \\
(\%)\end{array}$ \\
\hline & 位 & 200 & 77 & 63 & 100 & 87 & 55 \\
\hline & 分 & 100 & 98 & 62 & & & \\
\hline & 分 & & & & 100 & 76 & 50 \\
\hline & 分 & 100 & 80 & 61 & 200 & 76 & 63 \\
\hline 60 & 分 & 100 & 74 & 60 & 100 & 87 & 63 \\
\hline 2 & 時 & & & & 100 & 87 & 58 \\
\hline & 時 & & & & 100 & & \\
\hline
\end{tabular}

3g に埋没して与えたもので, 臨床観察上は中毒症状は 全く見られなかった. (第 3 表)両者を比皎してみるに前 者ではパラチオン摂取後 30 分にしてすでに Ch. E. は62 \%減少して扣り, 症候が本格的洦現するのは 1 時間 後であって, この時の Ch. E. は全く消失している. 赤 血球数も 30 分後一時下降するが, 反転して急激に增加 乙, 血色素冨, 血䌅は増加, 白血球像は好中球の増加, 淋巴球の減少を示して死亡したもので,アトロピンは Ch. E. の全消失後18分して皮下注射されたもので全く 效果は認められなかった。すなおち顕著な佂候が現われ てからのアトロピンの注射は意義がない. 後者に吊って は予防的意味のもとに試験されたものでアトロピンが生 体汇完全汇作用した時始めてパラチオンを給与したもの で，ホリドールが固型物とともに胃内撮联され吸収 されるのに約 30 分を要したとしても, 前者化比較して 1 時間ないし 2 時間の Ch. E. 女当然著しく低下ないし消 失すべきるのと思われるが，本例化和いては 1 時間後 66 \%，1時間 30 分後 $66 \% ， 2$ 時間後 $66 \%$ でアトロピンの前 処置儿より明らかに血清 Ch. E. の低下を防いでいるこ とを知った。季た Ch. E.のみならず赤血球数, 白血㧴 数も大なる変動はなく, 白血球像もまた变化訬くむし 万好酸性球，淋巴球の增加をきたして和り，血色素量す やや低下の傾向を示したが, 血糖のみは30分後および 1 時間後では $14 \mathrm{mg} / \%$ の増加をきたしたが， 2 時間後に は平常汇復した。な特一般症候の変化は何ら観察し得な かった。

第 7 例の 7 日までの Ch. E. の回復状態は当 $\mathrm{kg} 2 \mathrm{mg}$ すなわち半量を与兄られた第 3 例と酷似している．7日 目両者ともに $76 \%$ 前後となるに拉よんで Atropinum sulfuricum 当 $\mathrm{kg} 0.1 \mathrm{mg}$ を第 7 例他皮下注射した結 果, 第 3 例比較して健康時 Ch. E. と同価沉なるのに 6 日間早かった点より推して, アトロピン性 Ch. E.ル 対しその低下を防ぐととも恢復を助長する作用がある

第 3 表アトロピンによる治療試験成績

\begin{tabular}{|c|c|c|c|c|c|c|c|c|c|c|c|c|c|c|c|}
\hline \multirow{2}{*}{ 番号 } & \multirow{2}{*}{ 種 類 } & \multirow{2}{*}{ 别 } & \multirow{2}{*}{ 年令| } & \multirow{2}{*}{$\left|\begin{array}{cc}\mid & \text { 重 } \\
\mathrm{kg}\end{array}\right|$} & \multirow{2}{*}{$\begin{array}{c}\text { Parathion } \\
\text { 量 } \\
\end{array}$} & \multirow{2}{*}{$\begin{array}{l}\text { Atropin } \\
\text { 注 射 }\end{array}$} & \multirow{2}{*}{ 経過時間 } & \multirow{2}{*}{\begin{tabular}{|l} 
赤血球数 \\
$($ 万)
\end{tabular}} & \multirow{2}{*}{$\begin{array}{c}\text { 直色䇣量 } \\
(\%) \\
\end{array}$} & \multirow{2}{*}{ 白掉球数 } & \multirow{2}{*}{ 白 } & \multirow{2}{*}{ 血 } & \multirow{2}{*}{ 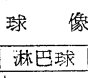 } & $(\%)$ & \multirow{2}{*}{ 血糖 $\mathrm{mg} / \%$} \\
\hline & & & & & & & & & & & & & & |单 球 & \\
\hline \multirow{6}{*}{7} & \multirow{6}{*}{ ビーグル稫 } & \multirow{6}{*}{ 牡 1} & \multirow{6}{*}{ 才 } & \multirow{6}{*}{8.8} & \multirow{5}{*}{$\begin{array}{l}\text { Pro. kg. } \\
\text { 4mg. }\end{array}$} & \multirow{5}{*}{$\begin{array}{l}\text { Pro. kg. } \\
\text { 0.1mg. } \\
20 \text { 分前 }\end{array}$} & 前 & 517 & 70 & 13,100 & 61 & 10 & 25 & 4 & 81 \\
\hline & & & & & & & 30 分 & 620 & 70 & 13,200 & 55 & 15 & 27 & 3 & 95 \\
\hline & & & & & & & 1 時聞 & 615 & 70 & 12,700 & 56 & 16 & 25 & 3 & 95 \\
\hline & & & & & & & 1 時間30分 & 603 & 70 & 13,600 & 52 & 14 & 28 & 6 & 89 \\
\hline & & & & & & & 2 時間 & & 68 & & & & & & 86 \\
\hline & & & & & \multicolumn{11}{|c|}{7 日後 Atropin. Pro. kg. 0.1mg. 芝下注射 } \\
\hline \multirow{7}{*}{8} & \multirow{7}{*}{ 雑 } & \multirow{7}{*}{ 转 } & \multirow{7}{*}{3 才 } & \multirow{7}{*}{12.4} & \multirow{6}{*}{$\begin{array}{l}\text { Pro. kg. } \\
20 \mathrm{mg} \text {. }\end{array}$} & \multirow{6}{*}{$\begin{array}{l}\text { Pro. kg. } \\
0.6 \mathrm{mg} . \\
\text { 30分後 } \\
\sim 3 \text { 時間 }\end{array}$} & 前 & 651 & 82 & 10,000 & 52 & 13 & 29 & 6 & \\
\hline & & & & & & & 1 時閪 & 611 & 86 & 10,900 & 54 & 18 & 22 & 6. & \\
\hline & & & & & & & $2 " 1$ & 687 & 88 & 8,000 & 53 & 12 & 29 & 6 & \\
\hline & & & & & & & 311 & 690 & 95 & 7,300 & 59 & 6 & 28 & 7 & \\
\hline & & & & & & & $4 " 1$ & 665 & 81 & & 60 & 16 & 20 & 4 & \\
\hline & & & & & & & $18 / 1$ & & & & 58 & 11 & 29 & 4 & \\
\hline & & & & & \multicolumn{11}{|c|}{ 2日目 Atropin. pro. kg. $0.3 \mathrm{mg}$ 度下注射 } \\
\hline 5 & & & 1 時 & 95分後 & Atropin. & ro. kg. 0. & ng 皮下注射 & 第1図索 & & & & & & & \\
\hline
\end{tabular}


第 4 表. 治療試験に扮ける血清 Cholinesterase の 活性価の変動 $(\%)$

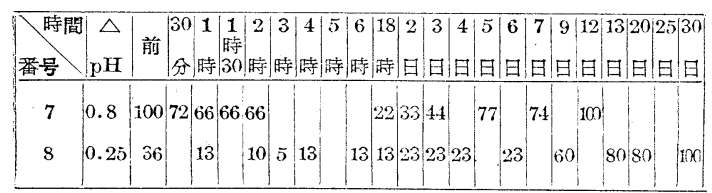

もののようである. 血派像についてみるに, 赤血球数は 一時増加したが漸時低下の傾向を示し, 血色素聕の変動 はなく, また好中球はむしろ減少, 好酸性球の増加, 淋 巴球も僅少ながら増加して和り, 第 5 例の赤血球数の一 時的減少後大增加し, 血色紊量もまた堌加, 好中球の增 加, 淋巴球の減少に比較すれば全く対逆的変化を示して いる.

第 8 例は第 4 例の笑験犬を引き継ざ使用したもので， 5 日前当 $\mathrm{kg} 3 \mathrm{mg}$ のパラチオンを給与され Ch. E. も 未回復のまま最少致死量の 5 倍量すなわち当 $\mathrm{kg} 20 \mathrm{mg}$ のパラチォンを Capsule に入れ, さらに肉片に埋包し て給与後30分から30分每に当 $\mathrm{kg} 0.1 \mathrm{mg}$ の Atropinum sulfuricum を6回, 総量 $7.4 \mathrm{mg}$ を 3 時間内に皮下注 射したもので, 臨床観察の結果は毒物摸取後50分より睡 孔は散大し， 1 時間 20 分後には $7 \mathrm{~mm}$ となった。. 2 時間 20 分後には噯気 3 回, 2 時間35分後には周囲黑色の特異 便を排泄するとともに, 頻数燰気, 2 時間55分後には軽 度の震戦叔よび不安の状强く，5時間後鼻噴数回，その 後暫くの間変状は鯰められなかったが，6時間20分後突 然叫鳴とともに驚愕したが, 以後症候に異常を認めず, 7 時間30分後食慨を給与したが平常と異ることはなかっ た.しかし食後15分嘔吐して胃内容物は全部昍出した。 さらに 2 時間後再度嘔吐したが, 体温に変動はなかっ

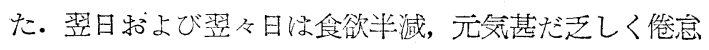

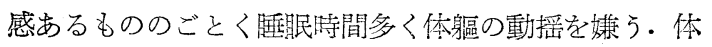
温暴常なし、これを血渡变状に和いて見るに赤血球数は 最初減少したが, 血清 Ch. E. の最も低下した 3 時間後 を頂点とし反転增加したけれども, わづか40万の增加し たのみで 4 時間後には汪とんど旧状に復した。

白血球数はやや減少している. 血血球像も多少その経 過中好中球，好酸球，淋已球の增減がみられたが著しい 変動とは考えられない。

血色素量も 3 時間後に13\%の増加をきたしたが，その 後間もなく回復し，血糖も軽度の上舁曲線を画いていた が，3時間を頂点として回復した．Ch. E. も36\%から

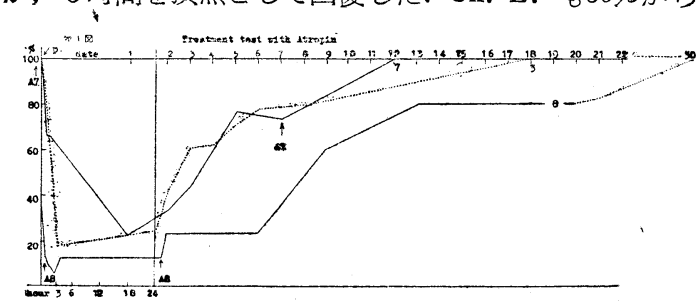

1 時間後には13\%低下 2 時間後には10\%となり，当然 30分ないし1時間以内に消失すると推考されるものが 3 時間後の $5 \%$ 最低として 4 時間目には $13 \%$ に回復し た.すなわちアトロピンの大量注射により Ch. E. の 消失を避け得たと思われる。市た Ch. E. は18時間後も

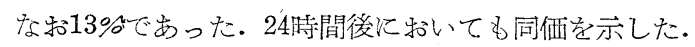
このときアトロピンを当 $\mathrm{kg} 0.1 \mathrm{mg}$ を30分每に 3 回皮 下注射した場合，2時間後には Ch. E.は25\%，5時間 後 $25 \%, 7$ 時間後 $25 \%, 20$ 時間後も25\%となって物り, 注射前と注射後明らかに $12 \%$ 増加が見られるので，ア トロピンによりある程度のCh. E. の增加ないしCh. E. の増加を制約している区子を除去することができると思 われる。

\section{N. 結 論}

当 $\mathrm{kg} 0.1 \mathrm{mg}$ のアトロピンにより静脈注射では10分 後から, 皮下注射では20分後から臨床的汇は瞳孔の散大 が認められ，血色美量はほとんぞ変仁なく，血糖は静脈 内注射では10分後軽度の増加があったが皮下注射の場合 には肝臓に和ける負担は多くはないと思われる。アト口 ピンは血清 Ch. E. の活性俩を試験管内においてはいう におよばず生体内応用において增加せしめることはなふ ったが，パラチオン中瑇の場合 Ch. E. の低下をある程 度阻止する才があるととも減少したCh. E. を幾分上， 抙せしめる作用があるものと考㝋られる。な款なたパラ チオン中毒時に和けるアトロピンの適用時期はでき得る 限り早期なるを可とし30分毎に当 $\mathrm{kg} 0.1 \mathrm{mg}$ 宛 6 回の 皮下注射により致死量の 5 倍量中善犬を治療し得た。

以上は昭和 29 年 4 月第37回日本獣医学会に扣いてその 要旨を発表した。

$$
\text { 齐献 }
$$

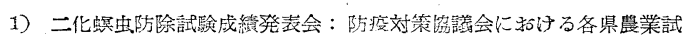
験場の成績, 昭和 27 年度. 2) 昭和26年度有機粼剂 Folidol に関する試 験成績：農林省農業改良局研究部, 昭和27年 6 月. 3) 村田道雄 : パラチ オン扎よびメチルパラテオン取趾基準令につマて, 植物防疫, 7, 7, (217)

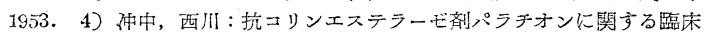

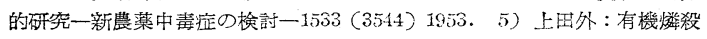

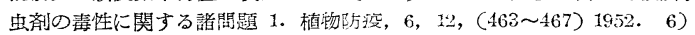
同2, 7, 2, (57 61) 1953. 7) KENGSLEY and MANKMAN: Parathion exposure and cholinesterase response of Quebec apple growers, Archives of Industrial Hygiere and Occupational Medicine. 6, 3, (252) 1952. 8) 池田, 菊地: Folidol 素性試験（第 2 報)農林省農業改夏部, 䀡和27年 6 月, (85).9) DUBORS and COON : Toxicology of organic phosphorus Containing insecticcides to mammals Arch Ind. Hygiene and Occupational Medicine, 6,1. （9）1952. 10）石井, 小原, 外：ホリドールの馬に対する㠓性訊験, 日 本獣医学䧴堎, 14，6，(477) 1952. 並びに第36回日本獣医学会講演. 11)

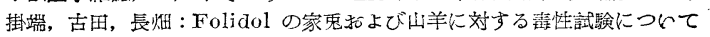
: 第37回日本䰻医学会講演. 12) WILDMAN and LEONARD : Physiological responeses to Paratizion exposure, 9, 1, (37) 1954. 13)沖中, 外: 自律神経系研究とその臨宋的応用の一面, 日本内科学会 雑誌，39，195, (313 332) 1950. 14) 上田, 佐藤：伹清 Cholinesterase の季節的動择, 医学々生物学, 3, 11, (360 363) 1943. 15) 凮部, 三 浦, 下田：馬血清中コリンエステラーゼに関する研究 I 、 日本獣医学雑 誌, 13，4，(211 219) 1951. 16) 三浦，岡部：同吕. 14, 1，(55 64) 1952. 17) 三浦: 同吕. 15, 5, 6, (273 279). 18) 高橋, 柴田: 蹦床 検相に使用できる簡単な血清コリンエステラーゼ定量法, 医学々生物学, $20.3,(96 \sim 98)$ 1951. 19) 永田, 高橋: 余らの血清コリンエステラー ゼ定量法におけるエゼリンの利用, 医学と生物学, $28,2,(83 \sim 86) \cdot 1953$.

日獣会誌 8 (1955) 